\title{
Talk about college curriculum reform based on the perspective of the social needs
}

\author{
Zhao junhui ${ }^{1, a}$ \\ ${ }^{1}$ Linyi University, Linyi Shandong 276400,China \\ ayssoft@126.com
}

Keywords: social needs; university curricula; reform; suggestions

\begin{abstract}
As the continuous development of current world's economy, changing of political pattern as well as constantly update of science and technology, updated requirements are presented for the development of knowledge-based economy, based on the current development of society, college curriculum reform is imperative, social needs is an important factor to consider for reforming college curriculum, this article positively analyzes the current college curriculum reform from the perspective of the social needs.

With the advent and development of the knowledge economy era, the role and status of college as a booster and the driving force are gradually appearing. Nowadays, the relation between college and society is increasingly close, the implementation of college curriculum determines the effect of mutual exchange of college and society to some extent. Thus, college curriculum reform should base on the needs of society, through some measures, like college curriculum's structure reforms and the creation of new college curriculum, to meet the new needs of current society, and promote China's overall economic and educational development.
\end{abstract}

\section{The impact of social need on college curriculum reform}

\section{A.The government plays dominant role during the reformation of university courses}

In the development of the college curriculum reform, government's regulation of its ideology has penetrated into the target of the curriculum until various processes and stages of the follow-up evaluation, in total, focused on the goal of college education, and based on this, mandatory open the ideological and political theory courses. After agree with the aims of education in the theory, related assessments are processed for feasibility of educational goals and lay the foundation for the opening of the course; Moreover, the impact of government on university education is also reflected in the standard and quality of curriculum, through strict supervising to guide and control curriculum, such as, official control for professional directory. The main content of professional directory in college curriculum is to clarify business specifications and work direction. Government can master the knowledge obtained in college based on macro-management of majors in college, which makes college education develops in the direction which is adapts to social reform [1].

\section{B.The impact of market on college curriculum changes}

Firstly, our country adopts planning system of college admissions under the control of country, as a student, the choice for college is mainly reflected in schools and major, courses are not within the scope of its consideration, which resulting some limitations in the area of college choosing; secondly, undergraduate majors have serious " empty shell" phenomenon. Curriculum is sheltered by major gradually since the relationship of admissions market and major sand and forms a major "empty shell" phenomenon. At the same time, the lack of curriculum information resources further exacerbated this "empty shell" phenomenon. Current online media has become the main channel for examinee to know universities when filling volunteer, and the richness of information resources on college website plays an extremely important role for candidates to know their school and major. Besides, the market have to ensure that students get used to working life, which is individual's career, corresponding to " Education Life ", which displays educational experience before and after working. Influenced by the current employment pressure, the market put forward higher 
requirements for a solid knowledge foundation and high overall quality, etc., so that universities and colleges need to build curriculum that matches their orientation.

\section{C.The specificity of third sector for college curriculum reform}

The so-called third sector is a non-governmental, non-profit organizations, providing public goods. Development of education in our country, there is a deficiency of third sector in current situation, such as small number, of weak entirety, and the presence of disorder on structure and function, this situation has brought certain negative effects to the college curriculum reform, it mainly performs in [2]:

(1) College curriculum reform is not sufficient for the reflection of social needs. In recent years, with the development of China's public welfare undertakings, the third sector has become the center of industry information collection and storage, which has great significance for social development. While the requirement of college curriculum reform for information resources collection, integration, analysis and other demanding is very high. To take full advantage of this information is a prerequisite for the implementation of the curriculum reform, which can provide advice and guidance to the college curriculum reform. but the third sector in China's economic society are deficiencies, causing that it cannot service to the country's college curriculum reform, and cannot provide the effective data and related information for the reform, making the response lag of college curriculum reform and weak pertinence. It cannot better meet the needs of current development.

(2) College curriculum reform is strong dependence of the Western developed countries. During the process of the curriculum reform, China lacks the college educational research, consulting and supervisory bodies as the Carnegie Foundation in United States, which determines China needs to learn from foreign experience for current curriculum reform. In this process, it will be deeply impacted by the foreign important research reports and related references, and the curriculum reform will break away from the national-conditions. For example, the introduced MBA is prepared for the people who wants to work in the U.S. companies. It has a certain concept and basis of American curriculum, and it is based on national conditions and development of the United States. Many countries have transplanted this model and related cases, and moved it rigidly into its own education system, but didn't make analysis and discussion of the adaptation of national- conditions.

(3) To accelerate the tendency of administration of college curriculum reform. With the development of the third sector, the academic third sector often through cooperation with the government to fight for the resources and support of development, and the government is very pleased to use the third sector to meet their own purposes. based on this kind of development patterns and status of the third sector in China, the college curriculum reform is not only intervened directly by government, but also indirectly intervened by the government in the name of the academic third sector, which impacts the process and effects of China's college curriculum reform.

\section{D. enterprises are unwilling to assume the impact of education responsibility}

Education in western developed countries have actually and repeatedly demonstrated the importance of the "industry-academy cooperation education", which strengthen the links between colleges and society, making the college curriculum reform can adapt to the needs of social development. For example, Germany's "dual system", this vocational education model is supported by the national legislation, and it is jointly built with college, in this model, students can learn some courses related to adapt to the future needs of work. It also can in virtue of companies to achieve the actual operation of the learned curriculum, enriching the students' practice experience, and providing valuable experience to students to participate in the social work. However, in China, the implementation of school-enterprise cooperation, is lagging behind. The Government does not introduce relevant policies to actively guide the school-enterprise cooperation, and for the details of the cooperation, it have not certain legal norms so that the school cannot find the enterprise for students' two-way business training, but enterprise also lacks initiative and enthusiasm.

Enterprise is different from the campus learning, it has marketability. It will have some innovative in college students' organization and process of practical training. However, in recent years, the number of students and aspiration accepted by enterprise gradually decline, which affects 
the implementation of the college curriculum reform to some extent [3].

\section{E. the complex impact of graduate employment market}

With the development of social and education, college curriculum reform should mainly use the feedback of graduate's employment direction as the reference information for reform, however, currently, the popularity development of China's economic and education make the feedback uncertainty. For example, in the employment process, a lot of "professional mismatch," employment exist, graduates are able to choose an occupation according to the previous specialty, and based on this situations, the college curriculum reform to a certain extent, increased its degree of difficulty and complexity of reform.

\section{The suggestion of the college curriculum reform under the perspective of social needs}

\section{A.to reduce unnecessary government intervention based on the law}

In the process of college curriculum reform, the strong intervention of government will have the adverse effects on college curriculum reform according to social needs. Thus, it should first fully implement the "Higher Education Law", to put the autonomy in running school of higher education institutions into practice, to greatly reduce the direct intervention of government in the college curriculum reform, and provide a relatively relaxed and free environment for the college curriculum reform. For example, the clear provisions of the Ordinance in the "Higher Education Law ": according to the teaching needs, Institutions of higher learning can autonomously develop the teaching Plan...... implement teaching activities. but seen from the current implementation, these provisions are not well implemented and executed, especially in terms of educational rights, the status quo to some extent causes some impacts on the aspects of running a college and other aspects, resulting in adversely affecting for curriculum reform in responding to the needs of society. Although the government intervention to college curriculum reform is legal, it should not deal the college with a comprehensive intervention or control. Government intervention should be in a range limits, it must follow the principle of minimal, as well as the principle of necessity and the principle of validity, and thus form a good interaction for college curriculum with the social needs, to promote the reform and development of curriculum.

\section{B.To accelerate the improvement of college curriculum to adapt to a new model of social needs}

At present, China's college education must focus on the cultivation of "T"-shaped talents, and build a personalized training model under the combination of professional and extensive, in which the personalization of professional courses and individual employment direction development of elective courses are emphasized to ensure courses stability, the specific embodiments are as follows:

(1) To deepen the reform of general education. In recent years, general education in our country has made great progress, it offers a variety of choices, and people can achieve free growth under the education. But it cannot meet the current development needs. first of all, the curriculum goals of general education should be made further clarity, so that students can understand their traditional arts by performing general education, and the creative thinking and critical thinking of students' are cultured, to enhance their sense of responsibility, understand and clear the responsibilities of as a member of society, and promote students' comprehensive development; Secondly, it should increase the optional courses' proportion of general education. In Harvard University, for example, the general education courses accounts for $30 \%$ to $35 \%$ of the teaching program, but in our country, the elective course of general education in college only has $6 \sim 14$ credits. Due to the national conditions, the proportion of ideological and political theory course are too large, reducing the proportion of elective course of general education. It should be made corresponding adjustment and reform. Based on the adjusted proportion, it should made careful scrutiny of its scientification, and refine the content of elective course to provide more hands-on training opportunities to students, enhance the manipulative ability of students and train the high-quality comprehensive talent for nation-building [4]. 
(2) To expand the areas of non-traditional class. On the basis of general education, in order to deal with the current employment pressures of graduate job market, it should actively expand the areas of non-traditional class, and promote its development. Non-traditional class embodies the flexible curriculum of "alteration according to changes", such as the experiential education under non-traditional courses. In its implementation, a student is seen as an individual with unique purpose. It can effectively improve the students' sense of social responsibility and participation in social affairs to make investment and planning of certain learning opportunities and process and conduct the learning and development of the skills, knowledge and the use of terms.

(3) To promote teachers' enthusiasm and level to participate in college curriculum reform.

Teachers are the main participants in college teaching, but should be the subject and major player of college curriculum reform. Based on this, it has a great facilitation for college curriculum reform to enhance college teachers' awareness of curriculum reform and encourage their active participation in college curriculum reform. When planning a single course, college teachers often put the content of teaching in the first place, rather than the objective of the course. They will be prepared starting from the knowledge logic of disciplines to arrange the course, with a certain degree of freedom and autonomy. So, in our country's college, teachers should be often carried out the learning and discussion of the aspects of ideological education, be made positive training, and be encouraged to participate in the curriculum reform to promote the college curriculum reform to be better.

\section{Conclusion}

In summary, the college curriculum reform under social needs is a complicated systematic project. It should start from the current situation of economic development, and from the perspective of social needs to make in-depth analysis and study of the difficulties faced by college students, and encourage multi-stakeholder to participate in the college curriculum reform, to effectively promote progress of China's reform and promote the good and rapid development of China's economy and education.

\section{References}

[1] Xu Gaoming. Change strategies of college course under social needs perspective - based on the survey of six universities in Jiangsu Province [J] Higher Education Research, 2012, 12:63-71.

[2] Xu Gaoming. University course reforms under social needs perspective [D]. Nanjing University, 2011.

[3] Yin Ningwei. College course reform oriented to the needs of the community [J]. Modern Education Management, 2011, 10:71-75.

[4] Shen Lan. Study on the general education curriculum provision of undergraduate based on social needs [D]. Southwest University, 2013. 